\title{
EXAMINATION OF THE INFLUENCE OF IMPACT ON TOBACCO CONSUMPTION IN SERBIA
}

\author{
Hasan Hanićl, Milica Bugarčić \\ *Corresponding authorE-mail: milica.bugarcic@bba.edu.rs
}

\begin{abstract}
A R T I C L E I N F O
A B S T R A C T

Original Article

Received: 18 November 2020

Accepted: 07 December 2020

doi:10.5937/ekoPolj2004217H

UDC 658.893:178.7(497.11)

The subject of this paper is the econometric analysis of tobacco demand in Serbia. The aim of this paper is to quantify the impact of income and socio-economic and demographic characteristics of households on tobacco expenditure based on microdata from the 2019 Household Budget Survey conducted by the Statistical Office of the Republic of Serbia according to the same methodology

Keywords:

income elasticity, tobacco expenditure, Engel curves, significance, hypothesis

JEL: C21, C51, D10, D12 applied by the European Union Agency for Statistics. The influence of these factors was quantified on the basis of seven different functional forms of Engel curves, which are most often used in econometric empirical research. Based on the estimated parameters of the empirical specifications of Engel curves and the elasticity derived from them, the hypothesis of inelasticity of demand for tobacco products in relation to household income was tested.
\end{abstract}

(C) 2020 EA. All rights reserved.

\section{Introduction}

One of the most stable connections in the field of economics was established by Ernst Engel back in 1857. Analyzing the structure of expenditures of a relatively small set of households, he found that there is a high degree of correlation between the share of expenditures for certain products and services and the level of household income and that this dependence determines the type (rank) of needs. He found that the share of expenditures in low-income households for products that meet the necessary needs, such as food products, is relatively high, while such share is relatively small in households with high income. The share of expenditures for relatively necessary or relatively luxurious products is approximately the same for households with lower and higher income (Milojević et al., 2020). Adopting the logical assumption that as household incomes increase, they actually adopt a pattern of behaviour characteristic

1 Hasan Hanić, Professor Emeritus, Belgrade banking academy, Zmaj Jovina 12, Phone: +38163234304, E-mail: hasan.hanic@bba.edu.rs, ORCID ID (https://orcid.org/0000-00027096-7685)

2 Milica Bugarčić, Asistant Professor, Belgrade banking academy, Zmaj Jovina 12, Phone: +381644641881, E-mail: milica.bugarcic@bba.edu.rs, ORCID ID (https://orcid.org/00000002-9327-9965) 
for higher-income households, Engel drew certain conclusions, which he explained in more detail in a paper published in 1895, which is considered a pioneering work in the field of family budget analysis.

The basic conclusions that Engel drew regarding the movement of the share of expenditures for necessary, relatively necessary and luxurious products, are called Engel's laws in his honor (Wold and Jureen (1953)). Summarized in one sentence, Engel's laws reveal that with the increase of household income: 1) the share (proportion) of expenditures for necessary goods in total expenditures decreases, 2) the share of expenditures for relatively necessary goods remains unchanged, 3) the share of expenditures for luxury goods in household income are growing. Engel's laws can be expressed in terms of elasticity of expenditures in relation to income as follows: expenditures for necessary goods are inelastic (coefficients of elasticity is less than one), expenditures for relatively necessary goods are normally elastic (coefficients of elasticity is equal to one), expenditures for luxury goods are inelastic (the coefficient of elasticity is greater than one.

The basic hypothesis from which this research started is that tobacco in Serbia has the status of a necessary good, i.e. that the elasticity of tobacco expenditure in relation to household income is less than one, i.e. that the demand for tobacco and tobacco products is inelastic in relation to household income. In addition to this basic hypothesis on the impact of income on expenditures, i.e. the share of tobacco expenditures, the paper examines the impact of socioeconomic and demographic characteristics of households on the patterns of behavior of households in terms of consumption of tobacco and tobacco products.

Researchers from different countries of the world have studied the dependence of tobacco expenditure on income and socioeconomic and demographic characteristics of the household. A large number of papers and research studies in this field have been published, especially in the last two decades. Arunatilake and Opatha (2000), who surveyed the impact of income on tobacco demand in 1999/2000 on a sample of 7,500 Sri Lankan households, found that the impact of income on income consumption is significant and that with the increase in income, the share of tobacco expenditure in household income decreases. Using data from the National Survey of Household Income and Spending and the Federal Office of Consumer Protection for 1992, 1994, 1996 and 1998, SesmaVázquez et al. (2002) analyzed the demand for tobacco in Mexico depending on the income of households, but also on the price of tobacco products and the regional affiliation of the household. They found that Mexican households spent on average about $4 \%$ of total disposable income on tobacco in the analyzed period and confirmed the assumption that households at lower income levels have a higher share of tobacco expenditure in total expenditure, compared to affluent households with a lower share of expenditures for this group of products. Manrique and Jensen (2004) examined the impact of income and a number of socio-economic and demographic characteristics of households (such as size of the household, average age, head of the household age and the number of household members who make earnings). The research was based on data from the surveys of 
consumption of 21,155 Spanish households conducted from April 1990 to May 1991 and was intended to explore the demand for tobacco. As control variables, they included the following in the model: level of education, ownership of the building in which the household resides, employment status, regional affiliation, type of settlement in which they live (urban or rural) and gender of the household head. The results of the empirical econometric analysis showed that male-headed households living in urban areas as well as households with a larger number of employed members consume more tobacco. In addition, they concluded that households whose owner is the owner of the building in which the household lives consume tobacco to a lesser extent; and that the demand for tobacco in Spain is inelastic (estimated value of income elasticity is 0.44). In 2005, AlSadat and associates analyzed the income elasticity of tobacco expenditures by analyzing the budget of Malaysian households and concluded that the demand for tobacco and tobacco products in the period from 1990 to 2004 was approximately normally elastic, i.e. that the income ratio elasticity is approximately equal to one, and that tobacco belongs to the group of relatively necessary or relatively luxurious goods. A few years later Yusof and Duasa (2010) analyzed the budgets of 2649 Malaysian households and concluded that gender of the household head, as a demographic variable, in addition to income, affects tobacco consumption in Malaysia significantly. Nguyen, Rosenqvist, and Pekurinen (2012) conducted an international cross-section analysis on household samples originating from 11 European countries that comprise data collected from household consumption surveys conducted between 1960 and 2009. The results of their study showed that the status of tobacco in terms of income elasticity and the nature of needs is different in different countries. In Finland, France, Germany, Ireland, Spain, Sweden and the United Kingdom, the demand for tobacco is inelastic (income elasticities are less than one), in Portugal the demand for this type of product is normally elastic, while in others countries - Austria, Italy and the Netherlands, tobacco has acquired the status of an inferior product with negative values of income elasticity. On a relatively large sample of 13,866 households in Jordan, Al-Habashneh and Al-Majali (2014) examined, among other things, the impact of household size on tobacco consumption and found that this variable did not significantly affect the dependence of Jordanian household expenditure on the level of disposable income. Çetinkaya, Erkam and Basaram (2014) assessed the impact of income, level of education, household size and age structure of the household on the demand for cigarettes. They used the log-log functional form of the Engel curve, which they found to best represent the dependence of tobacco consumption on household income, based on data from household consumption surveys conducted by the Statistical Institute of Turkey collected in period from 2003 to 2011. These researchers found that the value of income elasticity in the observed period varied from 0.13 to 0.40 , that the influence of the level of education of the household head was significant in all years of the analyzed period, and that the variable Age structure of the household had a significant impact only in three years.

In our region, Tričković (1971) was the first author who, as part of a comprehensive analysis of family budgets based on the annual survey of the Federal Bureau of 
Statistics on the consumption of 13,117 Yugoslav households conducted in 1963, with data on annual expenditures for 16 groups of products and services, with distributions for three basic socio-economic groups of households - agricultural, mixed and labour, quantified the impact of income on tobacco expenditures and estimated that income elasticities for the three mentioned socio-economic groups of households are $0.50,0.63$ and 0.60 respectively. Ten years later, based on the annual survey on the consumption of 5,770 Yugoslav working-class households which was conducted in 1978, Hanić (1982) estimated that the elasticity of tobacco expenditure in relation to household income was 0.73 , which confirmed the earlier finding of inelastic demand for tobacco and tobacco products in relation to the income of Yugoslav households in the period from 1963 to 1978 .

Until recently, the analysis of tobacco consumption based on the survey on family budgets was not the subject of more detailed research in our area. A special impetus to the study of the impact of income, prices, socio-economic and demographic characteristics of households on tobacco expenditures was given by the authors as follows: Mugoša et al. (2017) in Montenegro, Prekazi (2017) in Kosovo, Gjika et al. (2020) in Albania, Aligorić et al. (2020) in Bosnia and Herzegovina, Jovanović et al. (2018), Hanić and Bugarčić (2019), Bugarčić (2019), Vladisavljević and others. (2020) in Serbia.

\section{Materials and methods}

The research was conducted by modeling tobacco consumption using seven functional forms of Engel curves that were most often applied in empirical econometric analysis of data obtained on the basis of household consumption surveys. These functional forms together with the income elasticities they imply are shown in Table 1.

Table 1. Analytical forms of functional dependence of expenditures on household income used in empirical analysis

\begin{tabular}{|l|l|l|}
\hline Model & Analythical expression & Elasticity \\
\hline Linear model & $Y=\alpha+\beta X$ & $E=\frac{\beta}{Y}$ \\
\hline Quadratic model & $Y=\alpha+\beta \log X+\gamma X^{2}$ & $E=\frac{X}{Y}(\beta-2 \gamma X)$ \\
\hline Double-logarithmic model & $Y=\alpha+\beta \log \log X$ & $E=\beta$ \\
\hline Linear-logarithmic model & $Y=\alpha+\beta \log \log X$ & $E=\frac{\beta}{Y}$ \\
\hline Logarithmic-linear model & $\log \log Y=\alpha+\beta X$ & $E=\beta X$ \\
\hline Inverse model & $Y=\alpha+\frac{\beta}{X}$ & $E=\frac{\beta}{\alpha X-\beta}$ \\
\hline Logarithmic-inverse model & $\log \log Y=\alpha-\frac{\beta}{X}$ & $E=\frac{\beta}{X}$ \\
\hline
\end{tabular}


The parameters of these functional forms were estimated by the method of least squares based on micro data collected by the Statistical Office of the Republic of Serbia using the Household Budget Survey in Serbia in 2019, with the application of Stata statistical software for data processing.

Two criteria were used to measure the degree of adjustment of a concrete model specification to empirical data, the coefficient of determination and the Akaike Information Criterion (AIC).

As the formulas in the last column of Table 1 show, income elasticity is a variable and depends on the level of household income, with the exception of the doublelogarithmic specification of the consumption model where the elasticity is constant for each income level. In order to approximate the (variable) expenditure elasticity implied by a specific Engel curve specification by a single number, the expenditure elasticity for a given income interval was calculated at the center of the estimated regression equation $\left(X_{S}, Y_{S}\right)$, where $X_{S}$ is the mean calculated as an arithmetic, geometric or harmonic mean of household income variable depending on whether the values of this explanatory variable are expressed on an arithmetic or logarithmic scale or on the scale of its reciprocal values.

The survey was conducted on the basis of micro data conducted by the Statistical Office of the Republic of Serbia through the Household Budget Survey 2019 according to the methodology harmonized with the methodology of the EU Statistics Agency, the International Labor Organization and the United Nations, which enables comparability of results with the results obtained by the researchers from other countries where Consumption Surveys are conducted according to the same methodology.

Table 2. Sample structure according to socio-economic characteristics

\begin{tabular}{|c|c|c|c|}
\hline \multicolumn{2}{|c|}{ Socio-economic and demographic characteristics } & $\begin{array}{l}\text { Number of } \\
\text { households }\end{array}$ & Share \\
\hline \multirow{2}{*}{ Gender of the head of household } & Male & 4162 & 0.66 \\
\hline & Female & 2192 & 0.34 \\
\hline & Total & 6354 & 1.00 \\
\hline \multirow{4}{*}{$\begin{array}{r}\text { Level of education of the head of } \\
\text { household }\end{array}$} & No education & 159 & 0.03 \\
\hline & Elementary & 1931 & 0.30 \\
\hline & Secondary & 3112 & 0.49 \\
\hline & Tertiary & 1152 & 0.18 \\
\hline \multirow{2}{*}{\multicolumn{2}{|c|}{ Beograd }} & 6354 & 1.00 \\
\hline & & 1245 & 0.20 \\
\hline \multirow{3}{*}{$\begin{array}{r}\text { Regional affiliation of the } \\
\text { household }\end{array}$} & Vojvodina & 1780 & 0.28 \\
\hline & Šumadija and Western Serbia & 1787 & 0.28 \\
\hline & Southern and Eastern Serbia & 1542 & 0.24 \\
\hline \multicolumn{2}{|r|}{ Total } & 6354 & 1.00 \\
\hline \multirow{2}{*}{ Household type } & Urban & \begin{tabular}{|l|}
3890 \\
\end{tabular} & 0.61 \\
\hline & Rural & 2464 & 0.39 \\
\hline & Total & 6354 & 1.00 \\
\hline
\end{tabular}




\begin{tabular}{|r|l|l|l|}
\hline \multicolumn{2}{|l|}{ Socio-economic and demographic characteristics } & $\begin{array}{l}\text { Number of } \\
\text { households }\end{array}$ & Share \\
\hline \multirow{3}{*}{ Size of household } & 1 & 1709 & 0.27 \\
\cline { 2 - 4 } & $2-4$ & 3831 & 0.60 \\
\cline { 2 - 4 } & $5-7$ & 762 & 0.12 \\
\cline { 2 - 4 } & $>7$ & 52 & 0.01 \\
\hline \multicolumn{2}{|l}{ Total } & 6354 & 1.00 \\
\hline
\end{tabular}

Source: Authors' calculation

The survey entailed 6354 households. Of the total number of households covered by the survey, i.e. the sample $66 \%$ are households whose heads are male; almost half (49\%) are households where the head of the household has secondary education; approximately one quarter are households from each of the four regions of Serbia; urban households account for $61 \%$; medium-sized households (two to four members) make up $60 \%$.

\section{Results and Discussion}

In 2019, every third household in Serbia had expenditure on tobacco, which means that in every third household at least one person consumed tobacco, while in 2006 every second household had expenditure on tobacco. The average monthly expenditure on tobacco of Serbian households in 2019 amounted to 6893 dinars, with the share of expenditure for tobacco in the total household income amounting to 8\%, while in 2006 the share was only $5 \%$.

Based on the data on household consumption in 2019, it has been determined that the share of expenditures for tobacco of smoking households in Serbia decreases with the increase of income. Arunatilake and Opatha (2000) in Sri Lanka and Sesma-Vázquez et al. (2002) in Mexico.

In terms of the gender structure of the household heads in the household in which at least one member consumes tobacco products, male households dominate $(73 \%)$. The share of tobacco expenditures of these categories of households is approximately the same, amounting to $8 \%$. Both sets of households are dominated by households whose head has completed secondary education. The largest number of households from the first group (35\% of them) live in the territory of Šumadija and Western Serbia, while the largest number of households from the second group (30\% of them) live in Belgrade. In terms of the type of settlement in which they live, both categories of households are mainly located in the city ( $56 \%$ and $68 \%$, respectively).

Table 3 shows the estimated values of the parameters of the used functional forms of Engel curves together with the indicators of the level of significance and the degree of representativeness of individual functional forms. 
Table 3. Estimated functional forms of Engel curves for the whole sample of households and for the subsample of households that are consumers of tobacco products

\begin{tabular}{|c|c|c|c|}
\hline Model & Year & All households & $\begin{array}{c}\text { Tobacco products consuming } \\
\text { households }\end{array}$ \\
\hline \multirow{6}{*}{ Linear } & Equation & $Y_{i}=307.862+0.032 X_{i}$ & $Y_{i}=3909.605+0.037 X_{i}$ \\
\hline & $p$-value & 0.000 & 0.000 \\
\hline & $F$ & 865.326 & 398.437 \\
\hline & Prob $>F$ & 0.0000 & 0.0000 \\
\hline & $R^{2}$ & 0.120 & 0.152 \\
\hline & $A I C$ & 124120.633 & 43927.450 \\
\hline \multirow{6}{*}{ Log-log } & Equation & $\log Y_{i}=2.346+0.555 \log X_{i}$ & $\log Y_{i}=2.346+0.555 \log X_{i}$ \\
\hline & $p$-value & 0.000 & 0.000 \\
\hline & $F$ & 381.449 & 381.449 \\
\hline & Prob $>F$ & 0.0000 & 0.0000 \\
\hline & $R^{2}$ & 0.146 & 0.146 \\
\hline & $A I C$ & 5529.123 & 5529.123 \\
\hline \multirow{6}{*}{ Log-lin } & Equation & $\log Y_{i}=8.099+0.000 X_{i}$ & $\log Y_{i}=8.099+0.000 X_{i}$ \\
\hline & $p$-value & 0.000 & 0.000 \\
\hline & $F$ & 238.569 & 238.569 \\
\hline & Prob $>F$ & 0.0000 & 0.0000 \\
\hline & $R^{2}$ & 0.097 & 0.097 \\
\hline & $A I C$ & 5654.627 & 5654.627 \\
\hline \multirow{6}{*}{ Lin-log } & Equation & $Y_{i}=-22403.407+2283.016 \log X_{i}$ & $Y_{i}=-30941.491+3403.832 \log X_{i}$ \\
\hline & $p$-value & 0.000 & 0.000 \\
\hline & $F$ & 865.718 & 450.111 \\
\hline & Prob $>F$ & 0.0000 & 0.0000 \\
\hline & $R^{2}$ & 0.120 & 0.168 \\
\hline & $A I C$ & 124120.288 & 43884.033 \\
\hline
\end{tabular}




\begin{tabular}{|c|c|c|c|}
\hline Model & Year & All households & $\begin{array}{c}\text { Tobacco products consuming } \\
\text { households }\end{array}$ \\
\hline \multirow{6}{*}{$\begin{array}{l}\text { Quadra- } \\
\text { tic }\end{array}$} & Equation & $Y_{i}=111.148+0.037 X_{i}-0.000 X_{i}^{2}$ & $Y_{i}=3464.937+0.046 X_{i}-0.000 X_{i}^{2}$ \\
\hline & $p$-value & 0.000 & 0.000 \\
\hline & $F$ & 436.932 & 203.955 \\
\hline & Prob $>F$ & 0.0000 & 0.0000 \\
\hline & $R^{2}$ & 0.121 & 0.155 \\
\hline & AIC & 124115.000 & 43921.271 \\
\hline \multirow{6}{*}{$\begin{array}{l}\text { Recipro- } \\
\text { cal }\end{array}$} & Equation & $Y_{i}=4219.964-\frac{7.559 e+07}{X_{i}}$ & $Y_{i}=9488.281-\frac{1.424 e+08}{X_{i}}$ \\
\hline & $p$-value & 0.000 & 0.000 \\
\hline & $F$ & 584.461 & 336.979 \\
\hline & Prob $>F$ & 0.0000 & 0.0000 \\
\hline & $R^{2}$ & 0.084 & 0.131 \\
\hline & AIC & 124372.841 & 43980.218 \\
\hline \multirow{6}{*}{$\begin{array}{l}\text { Log-reci- } \\
\text { procal }\end{array}$} & Equation & $\log Y_{i}=9.003+\frac{26703.341}{X_{i}}$ & $\log Y_{i}=9.003+\frac{26703.341}{X_{i}}$ \\
\hline & $p$-value & 0.000 & 0.000 \\
\hline & $F$ & 396.796 & 396.796 \\
\hline & Prob $>F$ & 0.0000 & 0.0000 \\
\hline & $R^{2}$ & 0.151 & 0.151 \\
\hline & $A I C$ & 5516.055 & 5516.055 \\
\hline
\end{tabular}

Source: Authors' calculation

Table 4 shows the estimated values of income elasticities for households that consume tobacco and for the sample of households that includes households that do not consume tobacco. The estimated values of income elasticities are presented separately for each functional form of the model of dependence of tobacco expenditure on household income, where in all cases, except in the case of the log-log Engel model, appropriate approximations of elasticity variable were made by using their means - arithmetic, geometric and harmonic mean instead of $x$ i $y$, depending on the form of the functional dependence of $\mathrm{y}$ on $\mathrm{x}$. 
Based on the numerical values of income elasticities estimated for individual functional forms for the entire sample and subsample of smoking households, it can be reliably concluded that tobacco in Serbia has the status of a necessary good with an elasticity less than one. The research conducted by Bugarčić (2019) on household samples in Serbia from 2006 to 2018 obtained the same result, which roughly corresponds to the results previously obtained by Tričković (1971) and Hanić (1982) who examined the income elasticity of household expenditures in the former Yugoslavia. Similar results were obtained by Manrique and Jensen (2004) in Spain, Nguyen, Rosenqvist and Pekurinen (2012) in Finland, France, Germany, Ireland, Spain, Sweden and the United Kingdom, Çetinkaya, Erkam and Basaram (2014) in Turkey.

Table 4. Income elasticities of household tobacco expenditure in Serbia, estimated on the basis of seven functional forms

\begin{tabular}{|c|c|c|c|}
\hline \multirow{2}{*}{ Model } & Means & All households & $\begin{array}{c}\text { Tobacco consuming } \\
\text { households }\end{array}$ \\
\hline \multirow{2}{*}{ Linear } & Arith. & 0.87 & 0.43 \\
\cline { 2 - 4 } & Arith. & 0.87 & 0.43 \\
\hline \multirow{2}{*}{ Log-log } & - & 0.56 & 0.56 \\
\cline { 2 - 4 } & - & 0.56 & 0.56 \\
\hline \multirow{2}{*}{ Log-lin } & Arith. & 0.00 & 0.00 \\
\cline { 2 - 4 } & Geom. & 0.00 & 0.00 \\
\hline \multirow{2}{*}{ Lin-log } & Arith. & 0.95 & 0.49 \\
\cline { 2 - 4 } & Geom. & 0.46 & 0.68 \\
\hline \multirow{2}{*}{ Quadratic } & Arith. & 0.94 & 0.54 \\
\cline { 2 - 4 } & Arith. & 0.94 & 0.54 \\
\hline \multirow{2}{*}{ Reciprocal } & Arith. & 0.48 & 0.25 \\
\cline { 2 - 4 } & Harm. & 0.75 & 0.38 \\
\hline \multirow{2}{*}{ Log-reciprocal } & Arith. & 0.40 & 0.33 \\
\cline { 2 - 4 } & Harm. & 0.64 & 0.49 \\
\hline
\end{tabular}

Source: Authors' calculation

According to the methodology of the Household Budget Survey conducted by the Statistical Office of the Republic of Serbia, which is harmonized with the methodology of the European Agency for Statistics, tobacco expenditures are classified into three subgroups: 1) Cigarettes, all types 2) Cigars and cigarillos and 3) Tobacco, cigarette paper and filters. Based on sample observations, it was determined that of the total number of households in which at least one member consumes tobacco products, $88 \%$ buy products from the first subgroup (Cigarettes - all types), almost $12 \%$ of them consume tobacco products from the third subgroup (Tobacco, cigarette paper and filters), so that the number of households that have expenditures for the second subgroup, which includes Cigars and cigarillos, is negligibly small.

While the share of expenditures for the group tobacco in household income is $8 \%$, the share of expenditures of tobacco consuming households for the subgroup Cigarettes - all types is $9 \%$, and for the subgroup Tobacco, cigarette and filter paper is $3 \%$. In 
accordance with the expectations of households with a lower level of income (52873 dinars) buy cheaper products from the subgroup Tobacco, cigarette paper and filters, unlike affluent households (whose average income is 84989 dinars) who buy products from the first subgroup (Cigarettes - all types).

Table 5. Income elasticities of expenditures for two subgroups of tobacco, for smoking and non-smoking households, in Serbia

\begin{tabular}{|c|c|c|c|c|c|}
\hline \multirow[b]{2}{*}{ Model } & \multirow[b]{2}{*}{ Means } & \multicolumn{2}{|c|}{ Cigarettes (all types) } & \multicolumn{2}{|c|}{ Tobacco, paper and filters } \\
\hline & & All households & $\begin{array}{c}\text { Tobacco } \\
\text { consuming } \\
\text { households }\end{array}$ & All households & $\begin{array}{c}\text { Tobacco } \\
\text { consuming } \\
\text { households }\end{array}$ \\
\hline \multirow{2}{*}{ Linear } & Arith. & 0.91 & 0.38 & 0.00 & 0.21 \\
\hline & Arith. & 0.91 & 0.38 & 0.00 & 0.21 \\
\hline \multirow{2}{*}{ Log-log } & 1 & 0.43 & 0.43 & 0.22 & 0.22 \\
\hline & 1 & 0.43 & 0.43 & 0.22 & 0.22 \\
\hline \multirow{2}{*}{ Log-lin } & Arith. & 0.00 & 0.00 & 0.00 & 0.00 \\
\hline & Geom. & 0.00 & 0.00 & 0.00 & 0.00 \\
\hline \multirow{2}{*}{ Lin-log } & Arith. & 0.00 & 0.43 & 0.00 & 0.26 \\
\hline & Geom. & 0.00 & 0.57 & 0.00 & 0.34 \\
\hline \multirow{2}{*}{ Quadratic } & Arith. & 0.97 & 0.44 & -2.32 & 0.63 \\
\hline & Arith. & 0.97 & 0.44 & -2.32 & 0.63 \\
\hline \multirow{2}{*}{ Reciprocal } & Arith. & 0.49 & 0.23 & -0.06 & 0.17 \\
\hline & Harm. & 0.78 & 0.34 & -0.09 & 0.25 \\
\hline \multirow{2}{*}{$\begin{array}{l}\text { Log-reci- } \\
\text { procal }\end{array}$} & Arith. & 0.35 & 0.27 & 0.12 & 0.15 \\
\hline & Harm. & 0.55 & 0.39 & 0.19 & 0.23 \\
\hline
\end{tabular}

Source: Authors' calculation

*Note: Income elasticities of expenditure for the subgroup Cigars and cigarillos are not shown due to insufficient number of observations in the sample

Table 5 provides an overview of income elasticities of demand for two subgroups of tobacco products, separately for the subsample of tobacco consuming households and the entire sample that includes non-smoking households. Numerical values of income elasticities of expenditures estimated on the basis of representative functional forms of Engel curves indicate that the demand for certain products belonging to these subgroups is also inelastic in relation to household income. A similar result was reached by authors Nguyen, Rosenqvist, and Pekurinen (2012) who studied the dependence of cigarette expenditure on household income in Finland.

By comparing the income elasticities of expenditures of all households included in the sample with the income elasticities of expenditures of the subsample of households in which at least one member has expenditures on tobacco products, based on the corresponding representative functional forms the conclusion can be drawn that differences in income elasticities are not significant. 
In addition to quantifying the impact of income that sets the framework for household consumption, the paper examines the impact of qualitative, socio-economic and demographic factors on tobacco consumption in Serbia. The influence of these factors was examined by introducing artificial variables into the consumption model. This segment of the research was conducted in two phases. In the first phase, hypotheses on the influence of qualitative factors were tested using the F and t-test, according to the number of modalities of the observed factors. In the second phase the assessment of parameters was made - evaluation of indicators of the influence of qualitative variables which have statistically significant influence on the consumption of tobacco and tobacco products.

Based on the value of $t$ statistics and the realized level of significance $(\operatorname{Prob}>t=0.7996)$, it can be reliably concluded that the variable Gender of the household head does not significantly affect the behavior of households in terms of tobacco consumption. The hypothesis about the influence of the level of education of the household head on the dependence of expenditures on the amount of income was tested using F statistics. The realized value of $F$ statistics and the associated level of significance (Prob $>F=0.0028$ ) suggest that the hypothesis that the level of education of the household head determines the differences in the behavior of households in the domain of tobacco consumption and tobacco products can be accepted.

The level of education of the household head significantly affects the demand for tobacco in the sense that the demand of households whose head has completed only primary school is elastic (income elasticity is 1.14), while the demand of households whose head has acquired higher education is inelastic (income elasticity 0.35), implying that with the increase of the formal level of education of the household head, the income elasticity of the demand for tobacco decreases. This result coincides with the findings of the authors Çetinkaya, Erkam and Basaram (2014) who investigated this phenomenon in Turkey.

Using the same methodological approach, the following was found: there are significant regional variations in household behavior patterns; household size is a significant determinant of household behavior as a consumer of tobacco products; and there are no statistically significant differences in the behavior of rural and urban households. Based on the obtained results, it follows that the demand for tobacco has a different status in households belonging to different regions: in households in Southern and Eastern Serbia tobacco has the status of a luxury product (income elasticity 1.17), in households living in Sumadija and Western Serbia the product has the status of a relatively luxurious or relatively necessary product (income elasticity 1.06). The relative impact of income on tobacco expenditure is different for households with different numbers of members, which is reflected in a wide range of variation in the numerical values of income elasticities depending on the number of household members. 
Table 5. Income elasticities of tobacco expenditure of certain categories of households estimated on the basis of alternative functional forms of Engel curves

\begin{tabular}{|c|c|c|c|c|c|c|c|c|}
\hline $\begin{array}{c}\text { Qualitative } \\
\text { features }\end{array}$ & Modalities & Lin & $\begin{array}{l}\text { Log- } \\
\log \end{array}$ & $\begin{array}{l}\text { Log- } \\
\text { lin }\end{array}$ & $\begin{array}{l}\text { Lin- } \\
\log \end{array}$ & Qua & Rec & $\begin{array}{l}\text { Log- } \\
\text { rec }\end{array}$ \\
\hline \multirow{4}{*}{$\begin{array}{c}\text { Level of } \\
\text { education of } \\
\text { the head of the } \\
\text { household }\end{array}$} & No education* & 0.53 & 0.64 & 0.00 & 0.49 & 0.59 & 0.13 & 0.17 \\
\hline & Elementary & 0.47 & 0.69 & 0.00 & 0.57 & 1.14 & 0.33 & 0.44 \\
\hline & Secondary & 0.46 & 0.57 & 0.00 & 0.50 & 0.75 & 0.27 & 0.35 \\
\hline & Tertiary/Higher & 0.47 & 0.40 & 0.00 & 0.50 & 0.35 & 0.26 & 0.25 \\
\hline \multirow{4}{*}{$\begin{array}{l}\text { Number of } \\
\text { household } \\
\text { members }\end{array}$} & 1 & 0.38 & 0.71 & 0.00 & 0.54 & 1.04 & 0.41 & 0.58 \\
\hline & $2-4$ & 0.40 & 0.51 & 0.00 & 0.47 & 0.46 & 0.29 & 0.35 \\
\hline & $5-7$ & 0.43 & 0.64 & 0.00 & 0.53 & 0.52 & 0.39 & 0.52 \\
\hline & More than 7 & 0.35 & 1.20 & 0.00 & 0.43 & 1.76 & 0.35 & 0.98 \\
\hline \multirow{4}{*}{ Region } & Belgrade & 0.36 & 0.47 & 0.00 & 0.38 & 0.48 & 0.20 & 0.26 \\
\hline & Vojvodina & 0.62 & 0.79 & 0.00 & 0.71 & 0.78 & 0.29 & 0.41 \\
\hline & Šumadija and Western Serbia & 0.30 & 0.47 & 0.00 & 0.42 & 1.06 & 0.25 & 0.30 \\
\hline & Southern and Eastern Serbia & 0.44 & 0.61 & 0.00 & 0.53 & 1.17 & 0.31 & 0.40 \\
\hline
\end{tabular}

Source: Authors' calculation

*Note: This result is not statistically reliable due to the insufficient number of observations in this subsample of households

\section{Conclusions}

Based on the numerical values of income elasticities of tobacco expenditures, estimated on the basis of micro data from the Household Budget Survey in 2019 using seven functional forms of Engel curves, it can be reliably concluded that household expenditures on tobacco in Serbia are inelastic in relation to income.

Using the same data and functional forms of Engel curves, household income elasticities were estimated for two subgroups of tobacco expenditures (Cigarettes, all types; and Tobacco, cigarette paper and filters) while for the third subgroup (Cigars and cigarillos) into which total expenditures are broken down, income elasticity could not be accurately estimated due to an insufficient number of observations. In line with the expected result, the demand for products belonging to the two mentioned subgroups of tobacco expenditures in 2019 was also inelastic in relation to household income.

In addition to quantifying the impact of income on household expenditure on tobacco as a group of tobacco products and two basic subgroups which have a dominant share in total tobacco expenditure, this paper examines the impact of a number of qualitative or demographic and socio-economic characteristics of households i.e. the impact of a head of the household on demand for tobacco products. Based on F-statistics, qualitative variables with three or more modalities were identified, which significantly affect demand, while the influence of qualitative variables containing only two modalities was tested using the t-test.

Based on the calculated value of F-statistics and the corresponding associated level of significance ( $p$-value), the hypothesis was confirmed that the level of education of 
the household head, size and regional affiliation of the household affect the demand for tobacco products. Based on the empirical value of t-statistics or realized level of significance ( $p$-value) the hypothesis is rejected that the gender of the household head and the type of settlement (urban / rural) affect the demand for tobacco products.

This finding on the absence of significant differences in the behavior of rural and urban households, and male or female household heads is completely different from the empirical results obtained by other cited researchers who examined the impact of these household characteristics.

From the set of obtained results, the following can be singled out: The level of education of household heads significantly affects the demand for tobacco meaning that the demand for tobacco of households whose head has completed only elementary school is elastic (income elasticity is 1.14), while the demand of households whose head has acquired higher education is inelastic (income elasticity 0.35), implying that as the formal level of education of the household head increases, the income elasticity of tobacco demand decreases.

Regarding the influence of the regional factor on the demand for tobacco, it was found that the demand for tobacco has a different status in households belonging to different regions: in households in Southern and Eastern Serbia tobacco has the status of a luxury product (income elasticity 1.17), in households living in Šumadija and Western Serbia, this product has the status of a relatively luxurious or a relatively necessary product (income elasticity 1.06), while for households living in Vojvodina and Belgrade, tobacco has the status of a necessary product (income elasticities are 0.78 and 0.26 , respectively).

The impact of income on household expenditures with different number of members is different and, measured by the income elasticity ratio, it varies from 0.47 to 0.98 , whereby based on representative functional forms of Engel curves, an unambiguous relationship between the number of household members and the level of income elasticity could not be established.

\section{Conflict of interests}

The authors declare no conflict of interest.

\section{References}

1. Al-Sadat, N. A., MOH, Z. Z., Haniza, M. A., UKM, S. A. J., USM, M. I. M. I., UM, S. L. A. K., \& Chaloupka, F. (2005). Demand analysis of tobacco consumption in Malaysia. Southeast Asia Tobacco Control Alliance (SEATCA).

2. Household Budget Survey Statistical Office of the Republica Serbia. (2019). Statistical Office of the Republica Serbia, Belgrade. [in Serbian: Завод за статистику Републике Србије, (2019), Анкета о потрошњи домаћинстава Завода за статистику Републике Србије]

3. Arunatilake, N., \& Opatha, M. (2000). The economics of tobacco in Sri Lanka. Sri Lanka Economic Journal, 3(1), 96 - 120, https://doi.org/10.11588/xarep.00003860 
4. Bugarčić, M. (2019). Exploring the influence of income on the demand for consumer goods -Theoretical-methodological bases and empirical application. Belgrade banking academy, Belgrade. [in Serbian: Бугарчић, М. (2019), Истраживање утицаја дохотка на тражњу за потрошним добрима -Теоријско-методолошке основе и емпиријска примена]

5. Çetinkaya, M., Erkam, S., Basaram A. (2014). Workplace Smoking Bans and Tobacco Consumption in Turkey: Evidence from 2003 to 2011 Household Budget Surveys. The Empirical Economics Letters, 13(11), 1171-1177.

6. Engel, E. (1857). Die Produktions und Consumtionsverhältnisse des Königreichs Sachsen. Zeitschrift des Statistischen Büreaus des Königlich Sächischen Ministeriums des Innern, 8 and 9.

7. Gligorić, D., Pepić, A., Petković, S., Ateljević, J., \& Vukojević, B. (2020). Price elasticity of demand for cigarettes in Bosnia and Herzegovina: microdata analysis. Tobacco Control. http://dx.doi.org/10.1136/tobaccocontrol-2019-055258

8. Gjika, A., Zhllima, E., Rama, K., \& Imami, D. (2020). Analysis of tobacco price elasticity in albania using household level data. International Journal of Environmental Research and Public Health, 17(2), 432. https://doi.org/10.3390/ ijerph17020432

9. Hanić, H. (1982). Models of complex analysis of consumer demand. Economic Faculty University of Belgrade, Belgrade. [in Serbian: Ханић, Х. (1982), Модели комплексне анализе потрошачке тражње].

10. Hanić, H., Bugarčić, M. (2019). Econometric modeling of household consumption of alcoholic beverages and tobacco by complete system of regression equations. $11^{\text {th }}$ International Scientific Conference: Econometric modeling in economics and finance Book of abstracts, Institute of Economic Sciences, Belgrade, 35-37.

11. Jovanovic, O., Zubović, J., Vladisavljević, M., Bodroža, D., Ljumović, I., Domazet, I., \& Đukić, M. (2018). Estimation of Tobacco Products Price and Income Elasticity using Aggregate Data. Economic Analysis, 51(3-4), 81-94.

12. Manrique, J., \& Jensen, H. H. (2004). Consumption of tobacco and alcoholic beverages among Spanish consumers. Southwestern Economic Review, 31(1), 41 56.

13. Moneta, A. \& Chai, A., (2013). The evolution of Engel curves and its implications for structural change theory. Cambridge journal of economics, 38(4), 895-923. https://doi.org/10.1093/cje/bet033

14. Nguyen, L., Rosenqvist, G., \& Pekurinen, M. (2012). Demand for tobacco in Europe-An econometric analysis of 11 countries for the PPACTE Project. National Institute for Health and Welfare, Finland.

15. Milojević, I., Mihajlović, M., \& Pantić, N. (2020). Prikupljanje i dokumentovanje revizijskih dokaza. Oditor - časopis za menadžment, finansije i pravo, 6(2) https:// doi.org/10.5937/Oditor2002077M 
16. Mugoša, A., Čizmović, M., Laković, T., \& Popović, M. (2017). Tobacco price elasticity in Montenegro: using the micro data from Household Budget Survey and Deaton demand model. Accelerating Progress on Effective Tobacco Tax Policies in Low- and Middle-Income Countries, Institute of Economic Sciences, Belgrade.

17. Prekazi, B. (2017). Estimating tobacco price elasticity in Kosovo: using the micro data from Household Budget Survey (2007-2017) and Deaton demand model. Accelerating Progress on Effective Tobacco Tax Policies in Low- and MiddleIncome Countries, Institute of Economic Sciences, Belgrade.

18. Vladisavljevic, M., Zubović, J., Đukić, M., \& Jovanović, O. (2020). Tobacco price elasticity in Serbia: evidence from a middle-income country with high prevalence and low tobacco prices. Tobacco Control. http://dx.doi.org/10.1136/ tobaccocontrol-2019-055262

19. Tričković, V., \& Hanić, H., (1996). Marketing research. Economic Faculty University of Belgrade, Belgrade. [in Serbian: Тричковић, В., \& Ханић, Х. (1996). Истраживање тржишта].

20. Tričković, V., (1971). Study of consumer demand with special emphasis on the analysis of family budgets. Institute of Social Sciences-Center for Economic Research, Belgrade. [in Serbian: Tričković, V. (1971). Проучавање потрошачке тражње са пособним освртом на анализу породичних буџета].

21. Wold, H. and Jureen, L., (1953). Demand analysis. John Wiley And Sons, Inc, New York.

22. Yusof, S.A. and Duasa, J., (2010). Consumption patterns and income elasticities in Malaysia. Malaysian Journal of Economic Studies, 47(2), pp.91-106. 